\title{
Analysis of the Implementation of the Standard Performance ABNT NBR 15.575/2013: A Case Study with Brazilian Constructors
}

\section{Fernanda Silva Moreira1, Rafaela Fujita Lima1', Luis Felipe Cândido², and João Carlos Gonçalves Lanzinha ${ }^{3}$}

${ }^{1} \mathrm{DEC}$ - Department of Civil Engineering, Christus University Center - Faculty of Engineering, Av. Dom Luís, n. 911, 60160-230, Fortaleza, Brasil

${ }^{2}$ DEC - Department of Civil Engineering, Federal University of Ceará, Campus Crateús, Higway BR 116, Km 03, 63700-000, São Vicente, Brasil

${ }^{3}$ C-MADE - Centre of Materials and Building Technologies, University of Beira Interior - Faculty of Engineering, Calçada Fonte Lameiro, 6200-001 Covilhã, Portugal

\section{Abstract}

The development of studies about the housing constructions developments came

Corresponding Author: Fernanda Silva Moreira fernanda.silva922@gmail.com

Received: 7 January 2020 Accepted: 21 April 2020 Published: 3 May 2020

Publishing services provided by Knowledge E

(c) Fernanda Silva Moreira et al. This article is distributed under the terms of the Creative Commons Attribution License, which permits unrestricted use and redistribution provided that the original author and source are credited.

Selection and Peer-review under the responsibility of the STARTCON19 Conference Committee. from the need to ratify the effectiveness of the construction systems to the detriment of the low quality of the final product related to civil construction, which was unfolded in the creation of ABNT NBR 15,575 / 2013 - Housing Constructions - Performance. However, its implementation is still a point of discussion among several companies in this field, besides there is a gap between the requirements and established criteria and the adequacy of the constructive practices. Thus, the present work aims to analyse, through a multiple case study, the process of implementation of the Standard Performance in Brazilian construction companies, focusing on the main difficulties of implementation. For that, semi-structured interviews were carried out in 5 constructors, being possible to identify the implementation process adopted by each company and its main difficulties of adequacy to the norm. Thus, it was possible to verify that although the standard performance is required, the increase in costs resulting from this requirement has delayed its implementation, being the main difficulty of adequacy. In addition, it was observed that although the implementation process of the regulations is incipient, any effort in its direction represents an improvement in the quality of the civil construction and, consequently, in the durability and useful life of the buildings.

\section{Introduction}

The Brazilian Civil Construction Industry ( $\mathrm{CCl}$ ), despite integrating a large portion of the Gross Domestic Product (GDP) of the country, is still marked by the low quality of the final product [9], failures to comply with technical norms and of processes and operations 
In this context, NBR 15.575 [1] represents an important milestone for improvement in the $\mathrm{CCl}$, since it establishes requirements and criteria, based on user requirements, that the building must achieve during use, acting as a parameter for a construction with higher quality from the project phase to the use phase [1].

However, despite the importance of norm and effort the different industry agent $([3,6,7,13])$ there are still difficulties of application and, especially, in your understanding $([8,11)]$. A survey conducted by CBIC [7] pointed out that only $69 \%$ of respondent recognize the importance of the Standard Performance, evidencing the need to deepen the discussions, as well as better disseminate this norm. Thus, it is questioned: how has Standard Performance impacted the builders of Brazil?

Thus, the present study aims to analyze how Brazilian companies are developing the process of implementing the Standard Performance. For this, a multiple case study was developed with 5 constructors, which made it possible to identify the importance of the normative, the main difficulties and the changes in the constructive processes influenced by the norm.

Thus, the present study was divided into 5 sections, the first being this introduction. In the second section the debate on the Standard Performance is deepened, presenting theoretical basis on the main difficulties to comply with the normative. In topic three, is exposed the adopted research method, indicating the strategy used for the data collection and the characterization of the subjects of the research. Then, in section four, the results are presented and discussed, followed by the final considerations and, finally, the references.

\section{Literature Review}

According to ABNT NBR 15575 (2013), performance can be understood as the behavior in use of a building and its systems and may vary depending on the exposure conditions and the perception of each user.

As performance is variable, the norm reunites a set of requirements and criteria established exclusively for residential buildings and their systems, based on user requirements, regardless of their shape or constituent materials [1], serving as reference for a construction with higher quality. The performance requirements of the standard are conditions that qualitatively express the attributes that the building housing and its systems must possess in order to meet the requirements of the user, while the criteria are quantitative specifications of performance requirements [4]. 
ABNT NBR 15.575 (2013) comprises six major areas and involves all the productive complexes of the construction chain [12]. Based on the Safety, Habitability and Sustainability guidelines, the norm is organized in six parts, according to the building systems, and subdivided into thirteen disciplines that refer to the requirements to measure the performance of building [10], as summarized in Figure 1.

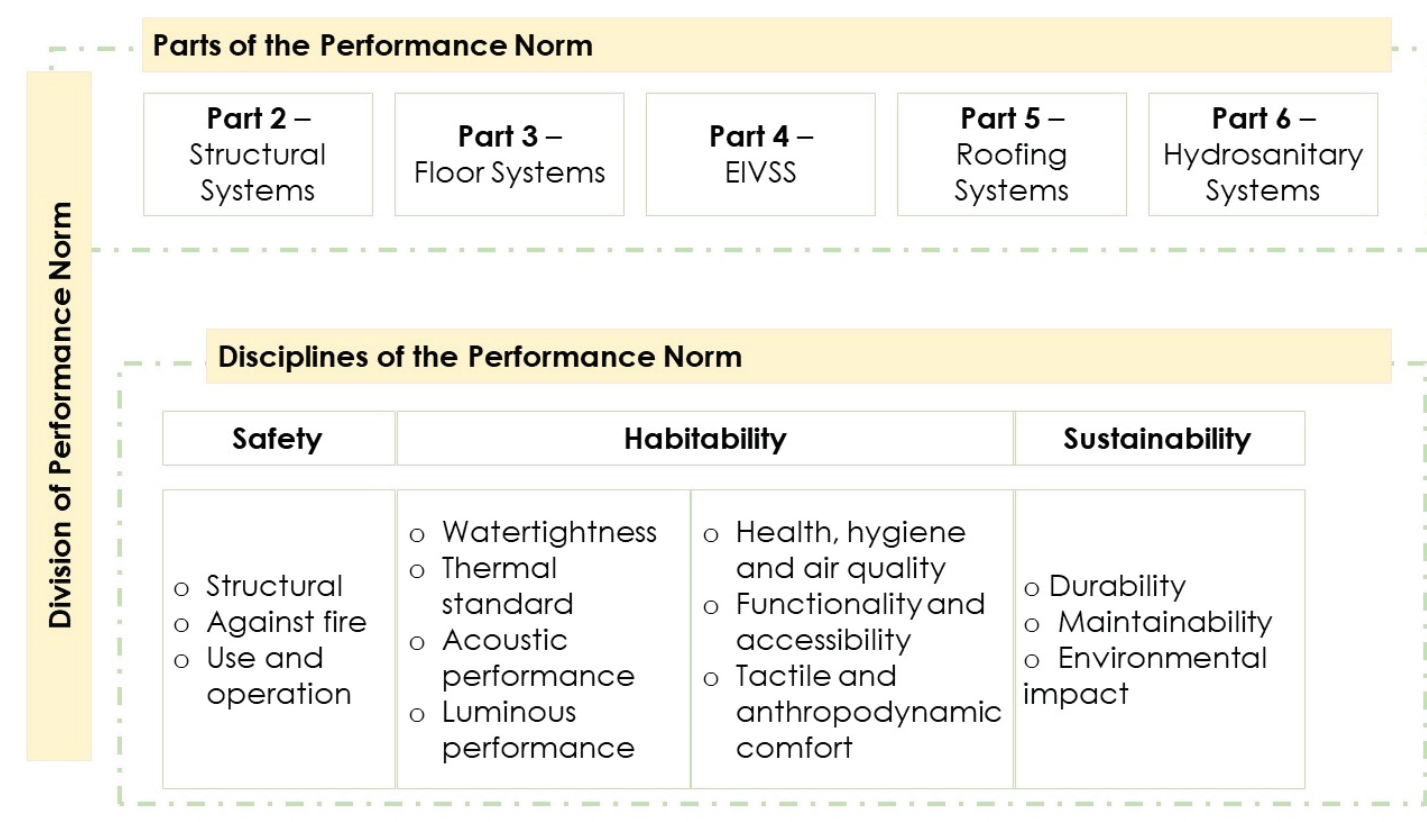

Figure 1: Standard Performance (EIVSS - External and Internal Vertical Sealing System. Source: Elaborated from [1] and [6].).

The disciplines of the norm allow a systemic evaluation of the construction and confer benefits of quality, value aggregation and constructive highlight, strongly influencing the economic scenario of the companies [5].

It should be noted that the standard under study does not include systems of electrical, logic and communication installations, claiming that existing norm already meet the requirements for these subsystems [1].

It is worth mentioning that the Standard Performance does not replace the pertinent norms, that is, ABNT NBR 15575 (2013) cites more than 150 standards which are broken down into more than one thousand other norms.

Perhaps for that, among other reasons, the normative still encounters difficulties of application, mainly in its understanding and in the instruction as to the use of its system [10]. 


\section{Methodology}

As a research method, a multiple case study [16] was carried out with a qualitative approach, with exploratory and descriptive objectives [8], with 5 Brazilian companies whose delimitation is presented in Figure 2.

The study was classified as qualitative because it was based on different realities in order to extract multiple meanings of the phenomenon analyzed [11]. As for the objectives, it was classified as exploratory and descriptive because it was sought to expose the characteristics of the studied group, while it explored exhaustively the object of study [14].

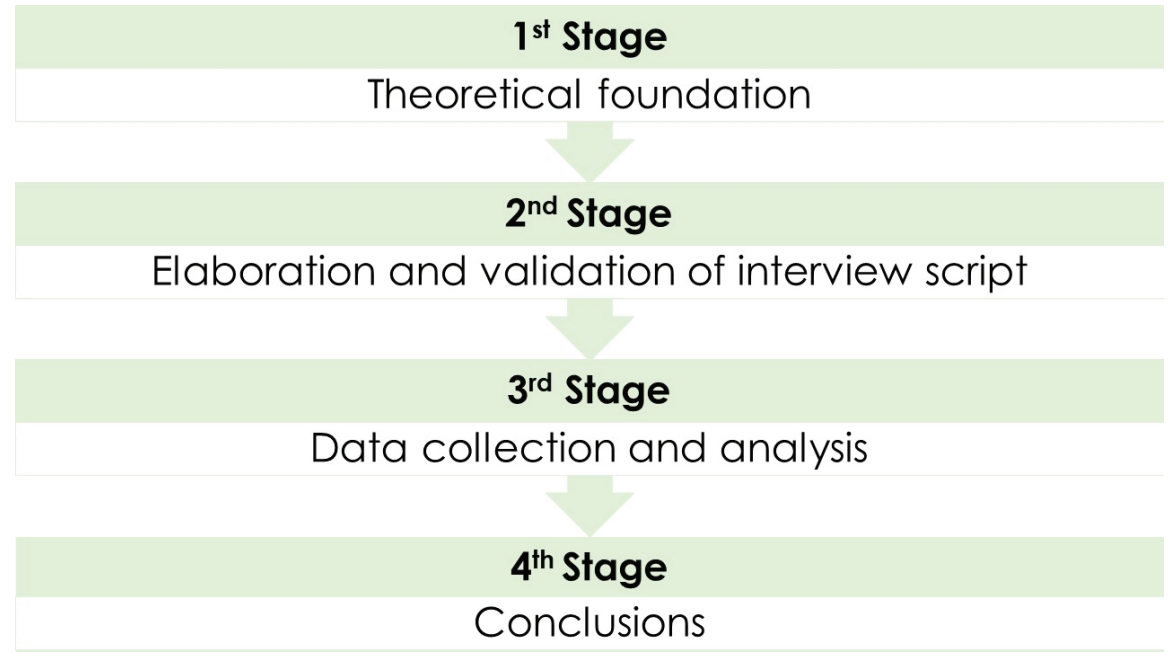

Figure 2: Delimitation of Research.

The data collection was developed through a semi-structured interview script [12], with 21 questions divided into three sections: (i) company characterization, (ii) Standard Performance and its implementation, and (iii) compliance with requirements acoustic performance. It is emphasized that a pretest was carried out and that the script remained the same. The results explored in this article correspond to $2^{\text {nd }}$ part of the interview.

Table 1 presents a characterization of the companies participating in the research

Furthermore, the use of semi-structured questions (Figure 3 ) in contrast with open questions, such as "What is your view on the performance standard? Is it important?", allowed the consolidation of the knowledge, starting from the interviewees, of how to meet the requirements of the standard.

The analysis of the results obtained is presented in the following topic. 
TABLE 1: Company characterization.

\begin{tabular}{l|l} 
Comp & Time of operation and scope \\
& $\begin{array}{l}25 \text { years, residential/ commercial } \\
\text { construction/ incorporation; } \mathrm{SH}^{*} \text { and } \\
\text { public constructions }\end{array}$ \\
& $\begin{array}{l}37 \text { years, residential/ commercial } \\
\text { construction/ incorporation }\end{array}$ \\
B & $\begin{array}{l}36 \text { years, residential/ commercial } \\
\text { construction/incorporation; } \mathrm{SH}^{*}\end{array}$ \\
C & $\begin{array}{l}40 \text { years, residential/ commercial } \\
\text { construction/ incorporation }\end{array}$ \\
D & $\begin{array}{l}10 \text { years, vertical residential and } \\
\text { commercial } \\
\text { Construction/incorporation }\end{array}$ \\
\hline E &
\end{tabular}

\begin{tabular}{|c|c|}
\hline \multicolumn{2}{|c|}{$\begin{array}{c}\text { Construction and Standard } \\
\text { Performance }\end{array}$} \\
\hline With & Without \\
\hline 2 & 2 \\
\hline 25 & 5 \\
\hline 3 & 2 \\
\hline 3 & 1 \\
\hline 3 & 0 \\
\hline
\end{tabular}

Interv.
Quality
Director
Coord. of
Planning
Project
Manager
Coord. Leen
and Green;
Architect
Quality
manager

*SH - Social Housing.

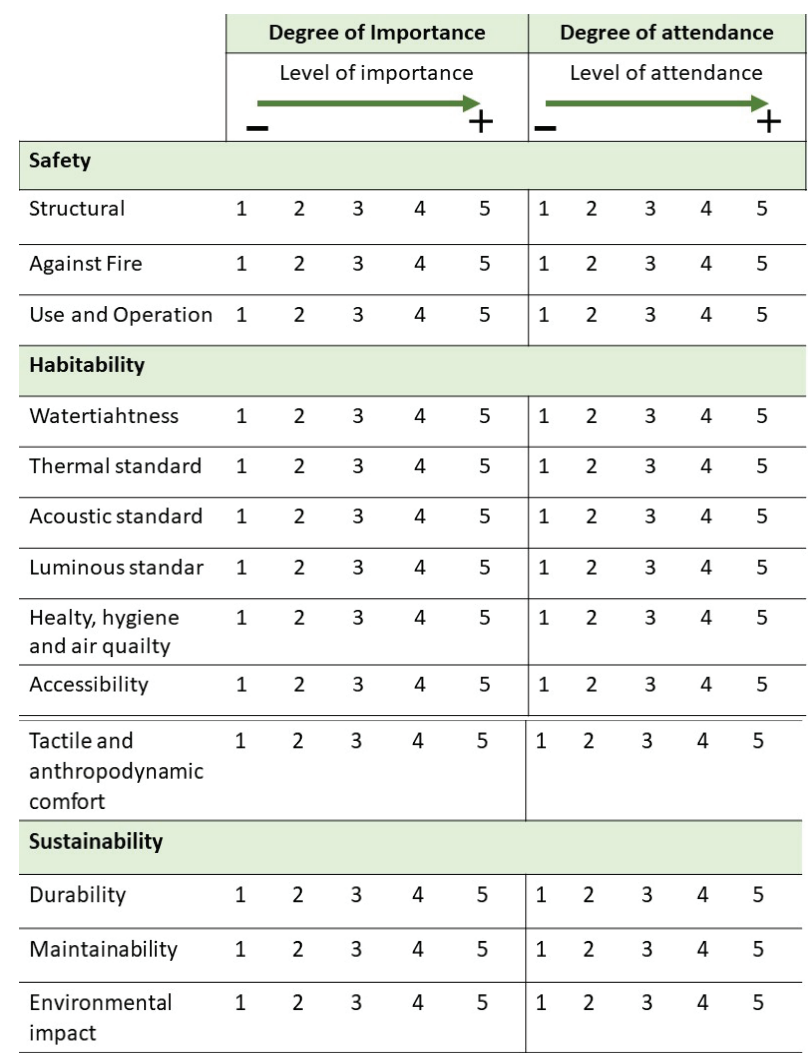

Figure 3: Structured questioning.

\section{Results and Discussion}

This section refers to the data collected in the second part of the interview script and was divided into two main parts: (i) the process of implementing the Standard Performance in 
each company studied, focusing on the methodology used; and (ii) the main difficulties faced by each construction company.

\subsection{Implementation Process}

Figure 4 shows the process adopted by each company for the implementation of the Standard Performance.

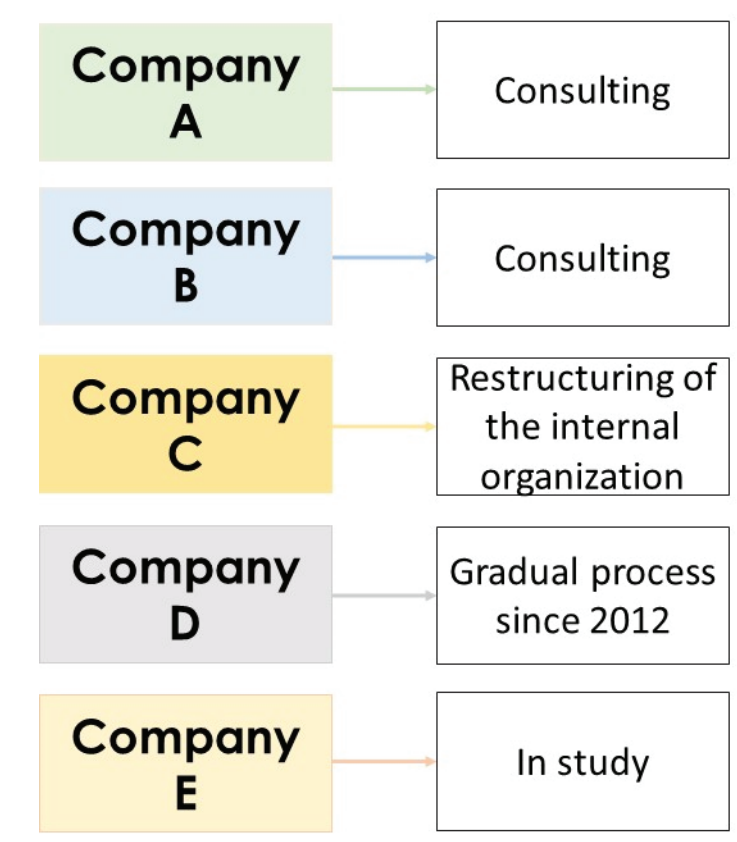

Figure 4: Process of Implementing the Standard Performance.

The following is describe the processes of each of the companies.

\subsubsection{Company A}

The area of activity of Company $\mathrm{A}(\mathrm{SH})$ dictated how the implementation of the Standard Performance was developed. The use of a patented constructive methodology (concrete walls), coupled with a project scope well delimited by the Caixa Econômica Federal (CEF), restricted this process.

The consultancy was developed in in a work of the same size as the usually builds by the company, being carried out tests of structural performance, watertightness, acoustic performance, thermal performance, fire safety and durability.

These evaluation methods combined project analysis and technical reports (structural performance), computational simulation (thermal performance) and on-site tests (other 
disciplines listed), concluding that the performance of the building reached the minimum level established in the norm.

The acoustic performance discipline was not tested, considering that the minimum performance would be met, according to the tests performed by SiNAT [3].

In addition, the company uses the results obtained with this consultancy for other works of the same size, provided they have the same architectural design, according to the guidance of the consulting firm that acted in this study of implementation of the Standard Performance.

\subsubsection{Company B}

The implementation of the Standard Performance in Company B (Figure 4) occurred through a consultancy carried out in one of its works. For this, a complete study of the project was carried out, indicating the actions necessary to meet the minimum level of the standard.

The guidelines obtained in this consultancy along with the ones developed by Inovacon and Sinduscon were generalized and became the standard for all housing works built by the company, as explained by the intervener.

\subsubsection{Company C}

Although Company $\mathrm{C}$ works in vertical and SH residential works, the process of implementing the normative under study was the same for the two construction systems, differentiating only the measures adopted to suit the standard in function of the different systems used.

The practice of benchmarking was adopted as a means to adjust the internal structure of the company to the requirements of the standard. According to the interviewee, knowledge about the norm was consolidated through participation in seminars, lectures, conversations with companies in the industry and reading the norm itself. It is worth mentioning that the manual developed by Inovacon-CE was the starting point for the studies of implementation of the Standard Performance in the company, as the interviewee points out.

To this end, procedures, control documents, work instructions, Service Checks (SC) and constructive methodologies were reviewed. Such modifications became necessary so that the company could attest to compliance with the conditioning of the standard. 
In addition, meeting the requirements of the Standard Performance became an integral part of service contracts signed with designers, reinforcing the importance of adequacy of the project to the guidelines of the normative under study.

Furthermore, the company evaluates the use of management software specific to the Standard Performance, promoting the integration of those involved in the process, aiming to delegate responsibilities.

It is worth mentioning that, at the time of the interview, the company had performed the tests specified by NBR 15.575 [1] in a social work, but the results were not yet available. The interviewee stressed that structural performance tests, watertightness, acoustic performance, thermal performance, fire safety and durability were carried out, including non-mandatory tests such as the acoustic performance of hydrosanitary installations.

\subsubsection{Company $D$}

The implementation of the Standard Performance began in 2012, when there was a public consultation on the normative.

Thus, the adaptation to its conditions occurred in a gradual manner, seeking a balance of cost/benefit, performing tests in works that do not have the obligation to follow the standard, aiming to build a prior knowledge about the practices adopted by the company in relation to the guidelines of the standard.

This process involved all the links in the construction chain, creating study groups to discuss some parts of the normative and conducting specific training for some points of the standard, such as DL.

In addition, involvement with Inovacon and Sinduscon during the preparation of the manuals was fundamental to consolidate the understanding of the standard, as the stakeholders pointed out.

\subsubsection{Company E}

The process of implementing the Standard Performance in Company $E$ is still in the initial stage, since the company does not have any work within the parameters of the standard, since of the projects in execution, two are residential buildings, homologated prior to the promulgation of the norm, and another is a commercial building. 
However, one of his works has Leed certification and in it will be carried out some tests related to Standard Performance. It is observed that the approach adopted is similar to that used by Company D.

\subsection{Main Difficulties}

Figure 5 summarizes the main difficulties faced by the companies studied.

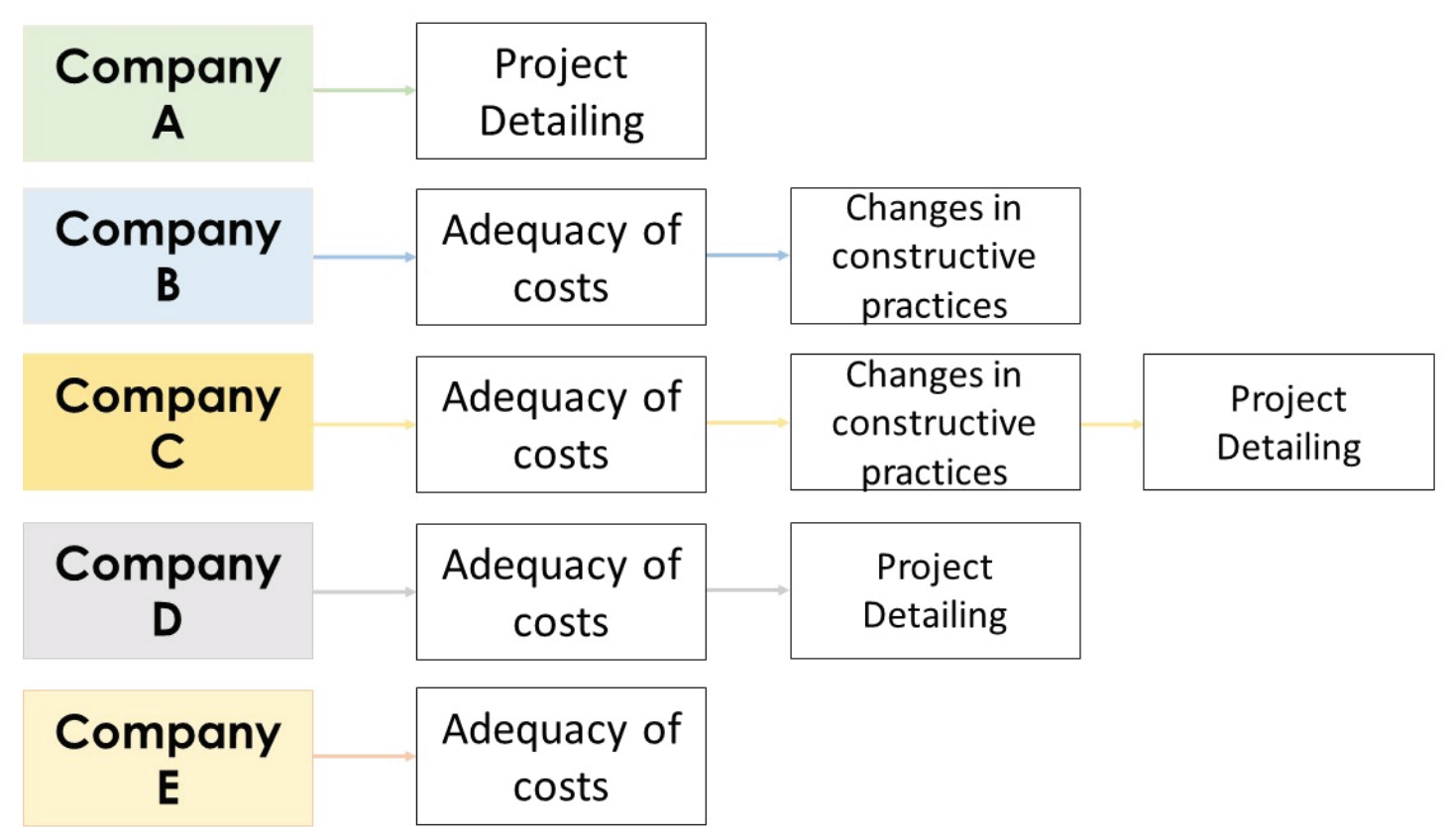

Figure 5: Main Difficulties.

Each of these difficulties is detailed next.

\subsubsection{Adequacy of costs}

It is observed that the adequacy of the costs to the guidelines of the Standard Performance is a common concern to the interviewees, due to the cost/benefit imbalance, as shown in Figure 6. As illustrated in Figure 6, the difficulty arises because the period of economic recession faced by the construction industry requires that companies reduced their production costs to become more competitive.

However, the financial resources needed to meet the conditioning the standard makes this balance difficult. This problem was described by CBIC [7], which showed that the increase in production costs would be passed on to the customer, being the 


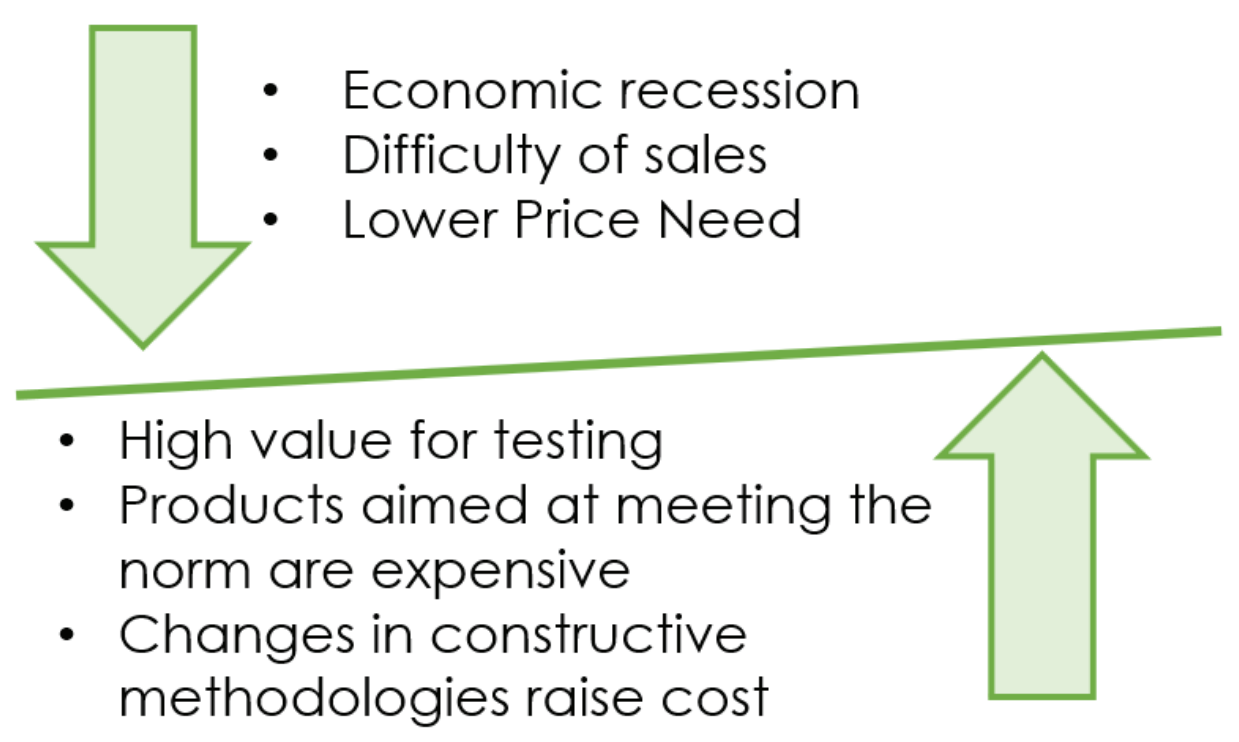

Figure 6: Imbalance in cost/benefit ratio.

same position adopted by Company B, Company $\mathrm{C}$ and Company $\mathrm{E}$ and commented by Company $A$ (although not translate into a difficulty for the company).

In Company E, according to the interviewee, the tests will be an item that will integrate the budget of future projects, trying to avoid that the budget is exceeded and looking at a way to balance this relation.

In Company $D$, the cost arising from the requirements of the standard should not reflect in the final customer, as the construction company has a legal obligation to comply with all applicable standards and the client should not pay more for this obligation.

\subsubsection{Project Detailing}

The increased level of detail of the project was pointed out by most of the interviewees as a difficulty in meeting the Standard Performance.

In this context, the Company $D$ interviewees pointed out that the architectural design was the one that presented the greatest difficulty of adaptation, because, when compared to complementary projects, such as electrical installations, the architecture falls short to comply with and cite technical norms.

Furthermore, the Company $\mathrm{C}$ interviewee pointed out that this increase in the level of detail directly impacts the amount invested in the design of the projects, thus justifying the resistance of the designers to adhere to this requirement, since there was a fear in presenting this increase to the finaly customer. 
For the representative of Company $A$, this new demand is the main difficulty of the company, since the projects until then developed are below the reality of the Standard Performance and the integral service of this item can translate significant costs to the project.

\subsubsection{Change in Constructive Practices}

It is observed that changes in constructive methodologies to meet the requirements of the standard tend to burden the constructive process because they are practices that the company has not yet mastered. For example, meeting acoustic performance requirements requires methods of insulation between residential units and the external environment that have proved costly, such as the use of acoustic frames (Company, B, $C$ and $D$ ), increase of underfloor thickness (Company D) and use of acoustic blanket (Company B).

In this context, compliance with against fire safety requirements also had a significant impact on costs, since available products that meet the requirements, such as temperature-sensitive expansive polymers that seal openings between floors and prevent fire and smoke from being transmitted from a pavement for the other, have the very high price, considerably increasing production costs, according to the interviewee of Company $\mathrm{C}$.

The need for change in constructive practices has a direct relation with the adequacy of costs, as, as punctuated by the interviewees of Company $D$, there are different solutions to meet the requirements of the Standard Performance, "the challenge is to balance costs and not allow that this reflects in the final customer, whether in relation to the sale price of the housing unit or the quality of the final product."

In addition, it is noted that the difficulty in meeting the requirements of some disciplines is related to cost and constructive practices, as detailed in the subsequent topic.

\subsubsection{Disciplines with higher difficulties of attendance}

Table 2 presents the main difficulties related to performance parameters.

It is observed that when the cost of products and the need for changes in construction methods dictate the level of difficulty to meet the requirements of a given discipline, as explained in topic 4.2.4. 
TABLE 2: Parametes with more difficulties.

\begin{tabular}{l|l|l} 
Discipline & Difficulties & Company \\
Acoustic & (1) Cost of insulation products; & B e D \\
performance & (2) Necessity of change in constructive methods; & B, C e D \\
& (3) Need to ensure performance "in the bone"; & D \\
& (4) Performance is related to the building environment. E \\
Fire Safety & (1) Cost of products; & C e D \\
Maintainability & (2) Necessity of change in constructive methods. & C e D \\
Thermal & (1) It depends on the user. & A, B e C \\
performance & (1) Function of the constructive method; & A \\
\hline
\end{tabular}

It should be noted that the definition of performance presented by NBR 15.575 [1] becomes an aggravating factor to meet the disciplines whose performance depends on the interaction of the building with the environment, as presented by the interviewees of Company A, Company B and Company $\mathrm{C}$.

In addition, Company D highlights the need to meet the standard of norm with the apartment without the final finishes, such as ceramic, as the customer can choose to receive it without.

\section{Final Considerations}

This study aimed to analyze the main difficulties for the implementation of the guidelines of the Standard Performance. For that, a multiple case study was carried out with 5 Brazilian constructors.

Thus, it was possible to verify that the greatest difficulty in meeting the constraints of the performance standard is the costs involved, since the requirements of the regulations tend to burden the construction process.

In this context, it is noted that there is a difficulty in finding suitable professionals to meet the demands of the performance standard, both in relation to the designers, the fear of increasing project costs, and in relation to the laboratories that perform the tests of the standard, since there are few companies that do them, thus raising the amount necessary to carry them out, depending on the law of supply and demand.

It was also concluded that in works of HS, because they are supervised by the CEF, the companies that work in this segment tend to be more careful in meeting the conditioners of the Standard Performance, not being observed the same concern in the constructors who do not act in this norm. Therefore, the end user has an important role to demand from such companies to prove compliance with the regulations. Finally, it can be inferred that the implementation of the Standard Performance, despite being incipient, 
deserves to be highlighted, given that any movement towards it is the beginning of an improvement in the quality of civil construction. Further research should include a higher number of companies.

\section{Acknowldgements}

This work was partially financed by Portuguese national funds through FCT - Foundation for Science and Technology, IP, within the research unit C-MADE, Centre of Materials and Building Technologies (CIVE-Central Covilhã-4082), University of Beira Interior, Portugal.

\section{References}

[1] ABNT. Edifícios habitacionais - Desempenho. ABNT NBR 15575:2013 (in Portuguese). Rio de Janeiro, Brasil,: ABNT, 2013.

[2] PROACUSTICA. Manual ProAcústica sobre a Norma de Desempenho. (in Portuguese), PróAcústica, n. 1, nov. 2013.

[3] BRASIL. Ministério das Cidades. Sistema Nacional de Avaliações Técnicas. Diretriz Sinat N 002 - revisão 01: Sistemas de paredes integrados por painéis prémoldados de concreto ou mistos para emprego em edifícios habitacionais. (in Portuguese), Brasília, DF: Ministério das Cidades, Brasil, 2016. Available in:<http://pbqph.cidades.gov.br/projetos_sinat.php>. Access in: 22 april 2019.

[4] CBIC. Análise dos critérios de atendimento à norma de desempenho ABNT NBR 15.575: estudo de caso em empresas do programa Inovacon-CE. Fortaleza: CBIC, 2016.

[5] CBIC. Análise dos critérios de atendimento à norma de desempenho ABNT NBR 15.575: estudo de caso em empresas do programa Inovacon-CE. Fortaleza: CBIC, 2016a.

[6] CBIC. Desempenho de edificações habitacionais: guia orientativo para atendimento à norma ABNT NBR 15575/2013. Fortaleza: CBIC, 2013.

[7] CBIC. Norma de Desempenho: Panorama Atual e Desafios Futuros/Pesquisa Setorial - Resumo Executivo. Brasília: CBIC, 2016b.

[8] COLLINS, J.; HUSSEY, C. Pesquisa em Administração: um guia prático para alunos de graduação e pós-graduação. 2. ed. Porto Alegre, Brasil: Bookman, 2005.

[9] FANTONI, B. B.; CASSILHA, S. A.; and IAROZINSKI NETO, A. Análise do Impacto das Certificações de Qualidade nas Características Organizacionais em Empresas 
de Construção Civil. In: ENCONTRO NACIONAL DE TECNOLOGIA DO AMBIENTE CONSTRUÍDO, 16., 2016, São Paulo. Anais... São Paulo: ENTAC, 2016.

[10] LORENZI, L. S. Análise Crítica e Proposições de Avanço nas Metodologias de Ensaios Experimentais de Desempenho à Luz da ABNT NBR 15575 (2013) para Edificações Habitacionais de Interesse Social Térreas. 2013. 245p. Thesis (Doutorado em Eng. Civil). Universidade Federal do Rio Grande do Sul, Porto Alegre, RS, Brasil, 2013.

[11] RICHARDSON, R. J. Pesquisa social: métodos e técnicas. 3. ed. São Paulo, Brasil: Atlas, 2011.

[12] SINDUSCON-DF. Avaliação do Desempenho Acústico de Edificações em diferentes sistemas construtivos, conforme a Norma de Desempenho ABNT NBR 15575/2013. 201 .

[13] YIN, R. K. Estudo de Caso: planejamento e métodos. 5. ed. Porto Alegre, Brasil: Bookman, 2015. 